\title{
Spatiotemporal patterns of the forage-livestock balance in the Xilin Gol steppe, China: implications for sustainably utilizing grassland-ecosystem services
}

\author{
QU Yingbo ${ }^{1}$, ZHAO Yuanyuan ${ }^{1,2^{*}}$, DING Guodong ${ }^{1,2}$, CHI Wenfeng ${ }^{3}$, GAO Guanglei ${ }^{1,2}$ \\ ${ }^{1}$ Key Laboratory of State Forestry Administration on Soil and Water Conservation, Beijing Forestry University, Beijing \\ 100083, China; \\ ${ }^{2}$ Yanchi Research Station, School of Soil and Water Conservation, Beijing Forestry University, Beijing 100083, China; \\ ${ }^{3}$ College of Resources and Environmental Economics, Inner Mongolia University of Finance and Economics, Hohhot 010017 , \\ China
}

\begin{abstract}
Understanding the spatiotemporal patterns of the forage-livestock balance is imperative for regionally arranging animal husbandry production while ensuring sustainable grassland-ecosystem service use. The Xilin Gol steppe is an important native grassland resource in Inner Mongolia Autonomous Region, China. This study aimed to elucidate the dynamics of the forage-livestock balance in the Xilin Gol steppe during the period 2000-2015. We evaluated the forage production and corresponding livestock carrying capacity (LCC) in the growing seasons of 2000-2015 using remote sensing data and field surveys. The spatiotemporal patterns of the forage-livestock balance were then assessed at regional, city (including city, county and banner), and village scales using statistical and household survey data. The results showed that both forage production and LCC decreased in the Xilin Gol steppe from east to west. During the period 2000-2015, the regional average forage production and corresponding LCC fluctuated without following a distinct trend, but were consistent with the variations in precipitation. The forage-livestock balance varied with time, space, and scale. At the regional scale, steppes were overgrazed in the early 2000s, but a forage-livestock balance or even grazing potential was achieved in other years. At the city scale, approximately half of the region exhibited a "forage-livestock balance" since 2000 . However, about half of the region still experienced overgrazing, which mainly located in the southwest sandy zones. Such changes may have been affected by the variations in grassland quality, forage production, compensation payment, and so on. We suggest a location-specific management scheme for grazing constraints, ecological compensation payment, and industry development to aid in harmonizing animal husbandry and environmental restoration, while promoting sustainable development goals by 2030 .
\end{abstract}

Keywords: forage production; livestock carrying capacity; forage-livestock balance; Xilin Gol steppe; sustainable development

Citation: QU Yingbo, ZHAO Yuanyuan, DING Guodong, CHI Wenfeng, GAO Guanglei. 2021. Spatiotemporal patterns of the forage-livestock balance in the Xilin Gol steppe, China: implications for sustainably utilizing grassland-ecosystem services. Journal of Arid Land, 13(2): 135-151. https://doi.org/10.1007/s40333-021-0053-x

\footnotetext{
${ }^{*}$ Corresponding author: ZHAO Yuanyuan (E-mail: yuanyuan0402@bjfu.edu.cn)

Received 2020-08-16; revised 2020-12-02; accepted 2020-12-20

(C) Xinjiang Institute of Ecology and Geography, Chinese Academy of Sciences, Science Press and Springer-Verlag GmbH Germany, part of Springer Nature 2021
} 


\section{Introduction}

Grasslands constitute the largest terrestrial ecosystem, accounting for approximately $40 \%$ of land worldwide (excluding Greenland and Antarctica; White et al., 2000). They provide significant ecosystem goods and services, such as livestock supply, soil and water conservation, and carbon storage (Zhao et al., 2017, 2020); the sustainable utilization of grassland resources is the foundation of regional ecosystem services provision, and economic and societal sustainability. As one of the most critical ecosystem services provided by grasslands, livestock provision will become increasingly important as global demand for animal protein and dairy products increases in the coming decades (Abbasi et al., 2016). The global demand for beef, mutton, and dairy was estimated to increase by $13.9 \%, 22.0 \%$, and $22.2 \%$, respectively, between 2011 and 2020 (OECD-FAO, 2011). The grazing management mode could strongly impact the regional richness, biomass, carbon sequestration capacity, and ecological health of grasslands (Atsbha et al., 2019). Therefore, animal husbandry and grassland ecosystem services are complementary and mutually restricted. China contains approximately $10 \%$ of the global grassland; grassland is one of the most essential ecosystems in northern China (Ni, 2002; Kemp et al., 2013). The livestock carrying capacity (LCC) refers to the maximum level of livestock rearing in a grassland ecosystem without compromising its production (Galt et al., 2000). However, the actual level of livestock production in grasslands exceeds the LCC and is becoming increasingly serious; thus, overgrazing and the degradation of grasslands have become a challenge for sustainable grassland utilization. Therefore, the spatiotemporal patterns of the LCC in natural grasslands and the forage-livestock balance must be studied for national policymaking, ecological protection, and the sustainable development of animal husbandry.

A series of studies have been conducted on regional forage production and LCC. The accurate evaluation of forage production methods can be categorized into three types, i.e., direct harvest, statistical modeling, and integrated models (Tilman et al., 2001). The commonly used statistical technique employs remote sensing data and ground surveying to establish statistical model, and forage production can then be retrieved from the statistical model (Zhao et al., 2014). With the development of remote sensing technology, models integrated with remote sensing data are becoming increasingly prevalent. Modeling net primary productivity (NPP) and then estimating forage production can compensate for the restrictions of ground surveys and is becoming more broadly utilized in regional, national, and even global-scale research. For example, Liu et al. (2015) estimated the NPP in the Xilin Gol steppe in Inner Mongolia Autonomous Region of China using the Carnegie-Ames-Stanford Approach (CASA) model with the normalized difference vegetation index (NDVI) and meteorological data as major inputs. Zhao et al. (2014) used ground survey data and the MOD17A2 NPP product for the growing seasons of 2005-2012 to retrieve and analyze the spatiotemporal patterns of the aboveground biomass in the Xilin Gol steppe. The use of this product in grasslands-related studies has been increased due to its higher resolution and accuracy (Zhao and Running, 2010; Guo et al., 2020; Ren et al., 2020).

The LCC must be estimated to accurately determine the forage-livestock balance level. Owing to the complexity of grassland ecosystems and the grazing mechanism, developing an LCC calculation strategy is a great challenge. Hobbs and Swift (1985) first proposed a nutrient supply method to estimate the LCC. Hao et al. (2011) improved this method and assessed the LCC in Alpine Kobresia grassland in Maduo County, China. Yu et al. (2004) conducted a study in Inner Mongolia according to the "determine LCC according to forage production" theory and produced a map of reasonable stocking rates. Li et al. (2009) utilized the GrazFeed model to estimate the forage-livestock balance level in Xilinhot City, China, using the feed supply, grassland, climate conditions, and livestock breeds as inputs. Among these strategies, "determine LCC according to forage production" has become the most frequently used one as it uses a direct and simple algorithm (Zhang et al., 2014).

The Xilin Gol steppe is located in the central Eurasian steppe, representing an important native grassland resource in Inner Mongolia (Hao et al., 2014). It has been identified as one of the most representative natural grasslands and provides an ecological buffer for northern China. Livestock 
grazing is the major industry in Xilin Gol League. However, owing to the stress caused by climate change and human activities, the Xilin Gol steppe has gradually been degraded, and conflict between grassland ecosystem stability and grazing is common (Batunacun et al., 2018; Zhao et al., 2018). Most previous studies on the Xilin Gol steppe focused on the changes in vegetation patterns and their responses to climate change and human activities (Tong et al., 2004; Li et al., 2012; Zhao et al., 2012; Gao et al., 2013; Zhao et al., 2014). However, knowledge of the forage-livestock balance level in this graze-dominant region remains elusive, which limits the formulation of rational grazing strategies and grassland sustainability, to an extent.

Therefore, this study aimed to estimate the spatiotemporal patterns of forage production and LCC in the Xilin Gol steppe from 2000 to 2015, by combining remote sensing, statistical, meteorological observation, and ground survey data. The forage-livestock balance level was then estimated at the regional, city (including city, county, and banner; hereafter called at the city scale), and village scales. Based on these results, we also discussed measures for grassland sustainable management and utilization for this region.

\section{Materials and methods}

\subsection{Study area}

The Xilin Gol League $\left(41^{\circ} 35^{\prime}-46^{\circ} 46^{\prime} \mathrm{N}, 111^{\circ} 09^{\prime}-119^{\circ} 58^{\prime} \mathrm{E}\right.$; Fig. 1$)$ is located in the central part of Inner Mongolia Autonomous Region of China, covering a total area of $2.03 \times 10^{5} \mathrm{~km}^{2}$. Natural grassland covers an area of $1.97 \times 10^{5} \mathrm{~km}^{2}$, accounting for $97.00 \%$ of the total area. The grazing grassland area accounts for approximately $86.70 \%$ of the total area, which includes typical, meadow, and desert steppe ecosystems, with the area percentages of $59.70 \%, 17.24 \%$, and $23.06 \%$, respectively. The study area belongs to the semi-arid and arid continental zone and experiences a temperate monsoon climate, with large annual temperature variation and irregular precipitation. The annual mean temperature is $0^{\circ} \mathrm{C}-3^{\circ} \mathrm{C}$ with the minimum of $-20^{\circ} \mathrm{C}$ in January and the maximum of $21^{\circ} \mathrm{C}$ in July; the mean annual precipitation is $200-400 \mathrm{~mm}$, which is mainly concentrated between July and September.

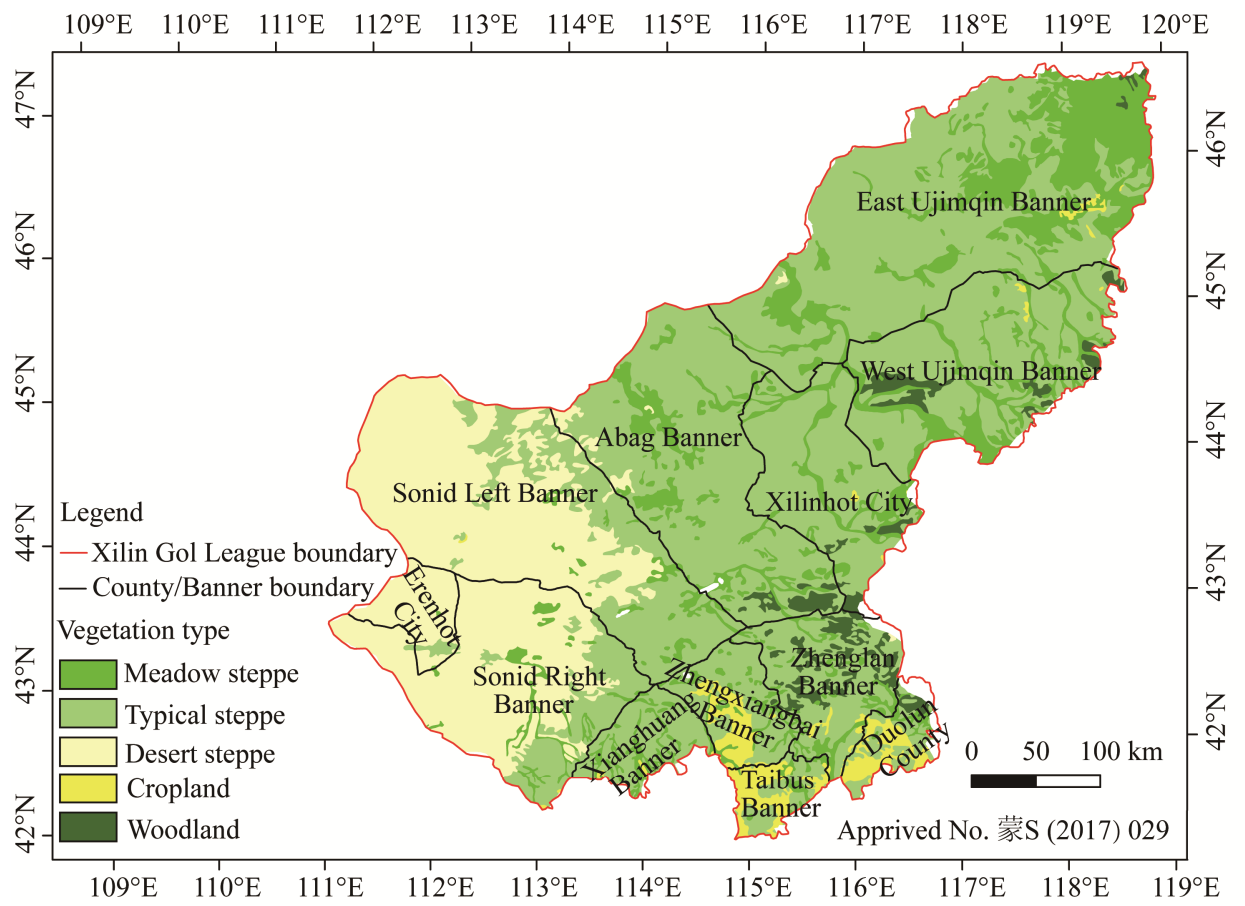

Fig. 1 Vegetation types in the Xilin Gol League, China 
The Xilin Gol League has 12 administrative regions, including two cities and ten counties and banners. According to the regional statistical data, the permanent population of the study area was $1.05 \times 10^{6}$ in 2017 , among which $2.25 \times 10^{5}(21.43 \%)$ were herders and $2.36 \times 10^{5}(22.48 \%)$ were farmers. The gross domestic product (GDP) from agriculture, forestry, animal husbandry, and fisheries of Xilin Gol League in 2017 was $2.07 \times 10^{10} \mathrm{CNY}$, of which the contribution of animal husbandry was $71.66 \%$ (Hao et al., 2017).

\subsection{Data acquisition}

Remote sensing data, meteorological observation data, statistical yearbooks, and questionnaire data were used in this study. The annual NPP with a spatial resolution of $500 \mathrm{~m}$ for 2000-2015 was obtained from the MOD17A3H dataset, which was derived from the Moderate Resolution Imaging Spectroradiometer (MODIS) NPP algorithm and driven by meteorological data (https://lpdaac.usgs.gov/) (Running et al., 2004, 2015; Running and Zhao, 2015). Meteorological data $\left(0.5^{\circ} \times 0.5^{\circ}\right.$ grid dataset V2.0), including precipitation, from April to September were downloaded from the China Meteorological Data Network (http://data.cma.cn/) for free. The data were then converted to a resolution of $500 \mathrm{~m}$ following the Christine interpolation method. Grassland type data were obtained from 1:1,000,000 vegetation maps to draw the spatial distribution of typical, meadow, and desert steppe habitats (Editorial Committee for Vegetation Map of China, 2007; Chi et al., 2018). The total number of livestock in each city, county or banner in the middle of the year was obtained from the statistical yearbooks of Inner Mongolia issued for 2000-2015 (Bureau of Statistics of Inner Mongolia Autonomous Region, 2000-2015). Additionally, as there were no village data in the Inner Mongolia Statistical Yearbook in 2015, we conducted a village-scale survey in Zhenglan Banner, which was a typical fragile steppe and threatened by desertification. A total of 21 villages were involved in the survey; the survey included the grazing mode in the Xilin Gol League, total livestock numbers in the middle of the year, ecological compensation from the country, income and cost of living, and so on.

\subsection{Calculation of forage production}

Forage production during 2000-2015 was characterized as the forage production density and total forage production, which were estimated using Equations 1 and 2.

$$
\begin{gathered}
A=\frac{\mathrm{NPP}}{0.45 \times\left(1+S_{\mu g}\right)}, \\
Q=S \times A,
\end{gathered}
$$

where $A$ is the forage production density $\left(\mathrm{g} / \mathrm{m}^{2}\right) ; S_{\mu g}$ is the proportion coefficient of biomass between the underground and aboveground parts of the steppe, which is 5.26, 4.25 and 7.89 for meadow, typical, and desert steppes, respectively (Piao et al., 2004); NPP is the annual net primary productivity $\left(\mathrm{g} \mathrm{C} / \mathrm{m}^{2}\right) ; Q$ is the total forage production $(\mathrm{g}) ; S$ is the grassland area $\left(\mathrm{m}^{2}\right)$; and 0.45 is the carbon-to-plant biomass conversion coefficient of NPP (Fang et al., 1996).

The forage production density was displayed with a spatial resolution of $500 \mathrm{~m}$, and its spatial distributions in 2000 and 2015 were compared. After calculating the area of the three types of steppe at each scale (i.e., the whole study area, cities (including cities, counties, and banners), and villages), we also recorded and analyzed the corresponding total forage production at regional, city, and village scales.

\subsection{Evaluation of livestock carrying capacity (LCC)}

We evaluated the proper LCC in the study area according to forage production and determined the grazing mode based on our field survey. In the Xilin Gol steppe, there was a grazing-forbidden period of approximately $40 \mathrm{~d}$ from April to early May. Grazing on natural grasslands continued from mid-May to September. From October to the next spring, cow and sheep were mainly fed with the remainder of the natural grassland and supplementary fodder (such as corn and artificial grassland biomass).

The Ministry of Agriculture of the People's Republic of China proposed sustainable grazing 
rules for different types of grasslands. Taking the temperate steppe as an example, the average sustainable grassland utilization rate for grazing was $45 \%-50 \%$, and it varied among the warm spring, warm autumn, and cold seasons; the corresponding value in the meadow steppe was slightly higher while the values in sandy grassland and desert grassland were lower. Daily forage consumption by livestock was also estimated by conducting surveys. A $40-50 \mathrm{~kg}$ sheep typically eats approximately $1.8 \mathrm{~kg}$ of dry forage per day, which is equivalent to one-eighth of the consumption by an adult cow $(>500 \mathrm{~kg})$.

In compliance with the corresponding national standard Calculation of Rangeland Carrying Capacity (NY/T635-2015) published by the Ministry of Agriculture of the People's Republic of China (2015), we calculated the proper LCC using the following formula (Zhang et al., 2014):

$$
C_{p}=\frac{Q \times U}{I \times D},
$$

where $C_{p}$ is the proper LCC of grassland (cattle heads); $Q$ is the total forage production (for the convenience of calculation, the unit is unified as $\mathrm{kg}$ here); $U$ is the grassland utilization rate in the growing season (from April to September), which is $52.5 \%, 50.0 \%$, and $42.5 \%$ for meadow, typical, and desert steppes, respectively, according to the Calculation of Rangeland Carrying Capacity standard (NY/T635-2015) (Ministry of Agriculture of the People's Republic of China, $2015) ; I$ is the daily food intake per animal $(14.4 \mathrm{~kg})$; and $D$ is the grazing time in the growing season, which is $143 \mathrm{~d}$ in the study area. As grazing management was adopted on the administrative unit, we calculated the proper LCC according to the area and forage production of different cities, counties, or banners, and then analyzed the spatial distribution of the proper LCC at the city scale.

\subsection{Assessment of the forage-livestock balance level}

The forage-livestock balance level was quantified using the overgrazing rate, which refers to the difference between the LCC and actual livestock (Eq. 4).

$$
C(\%)=\frac{C_{a}-C_{p}}{C_{p}} \times 100 \%,
$$

where $C$ is the overgrazing rate (\%); and $C_{a}$ is the actual number of livestock (cattle heads). In the study of $\mathrm{Xu}$ and Yang (2009), the forage-livestock balance level could be classified into five degrees: $C<-10 \%$ was potential grazing; $-10 \% \leq C<10 \%$ was forage-livestock balance; $10 \% \leq C<20 \%$ was light overgrazing; $20 \% \leq C<50 \%$ was moderate overgrazing; and $C \geq 50 \%$ was severe overgrazing.

The analysis was conducted at multiple scales. At the regional and city scales, we evaluated the forage-livestock balance level based on the modeling results and actual number of livestock from the statistical yearbook records. At the village scale, we assessed the data based on the modeling results and field survey of herder households from 21 typical villages in sandy zones.

\section{Results}

\subsection{Spatiotemporal pattern of forage production during 2000-2015}

The forage production density of the Xilin Gol steppe decreased from the northeast to the southwest (Fig. 2a and b) following the precipitation variation. As shown in Figure 2c, the average forage production density in the meadow steppe was highest $\left(86.18( \pm 10.95) \mathrm{g} / \mathrm{m}^{2}\right)$, while those in the typical and desert steppes were lower $\left(82.97( \pm 13.22)\right.$ and $22.70( \pm 4.87) \mathrm{g} / \mathrm{m}^{2}$, respectively). Owing to the size of the area, the total forage production of the typical steppe was highest, with an annual average value of $9.19 \times 10^{6} \mathrm{t}$, accounting for $71.15 \%$ of the total in the study area and exceeding those of the meadow $\left(2.75 \times 10^{6} \mathrm{t}, 21.33 \%\right)$ and desert $\left(0.97 \times 10^{6} \mathrm{t}\right.$, $7.52 \%$ ) steppes (Fig. 2d). For each region in 2015, the forage production density and total forage production in East Ujimqin Banner $\left(111.40 \mathrm{~g} / \mathrm{m}^{2}\right.$ and $4.78 \times 10^{6} \mathrm{t}$, respectively) and West Ujimqin Banner $\left(123.20 \mathrm{~g} / \mathrm{m}^{2}\right.$ and $2.62 \times 10^{6} \mathrm{t}$, respectively) greatly exceeded those in Sonid Left Banner $\left(34.43 \mathrm{~g} / \mathrm{m}^{2}\right.$ and $1.18 \times 10^{6} \mathrm{t}$, respectively), Sonid Right Banner $\left(30.92 \mathrm{~g} / \mathrm{m}^{2}\right.$ and $0.58 \times 10^{6} \mathrm{t}$, 
respectively), and Erenhot City $\left(21.32 \mathrm{~g} / \mathrm{m}^{2}\right.$ and $0.06 \times 10^{6} \mathrm{t}$, respectively). Details are provided in Table S1.

(a) 2000

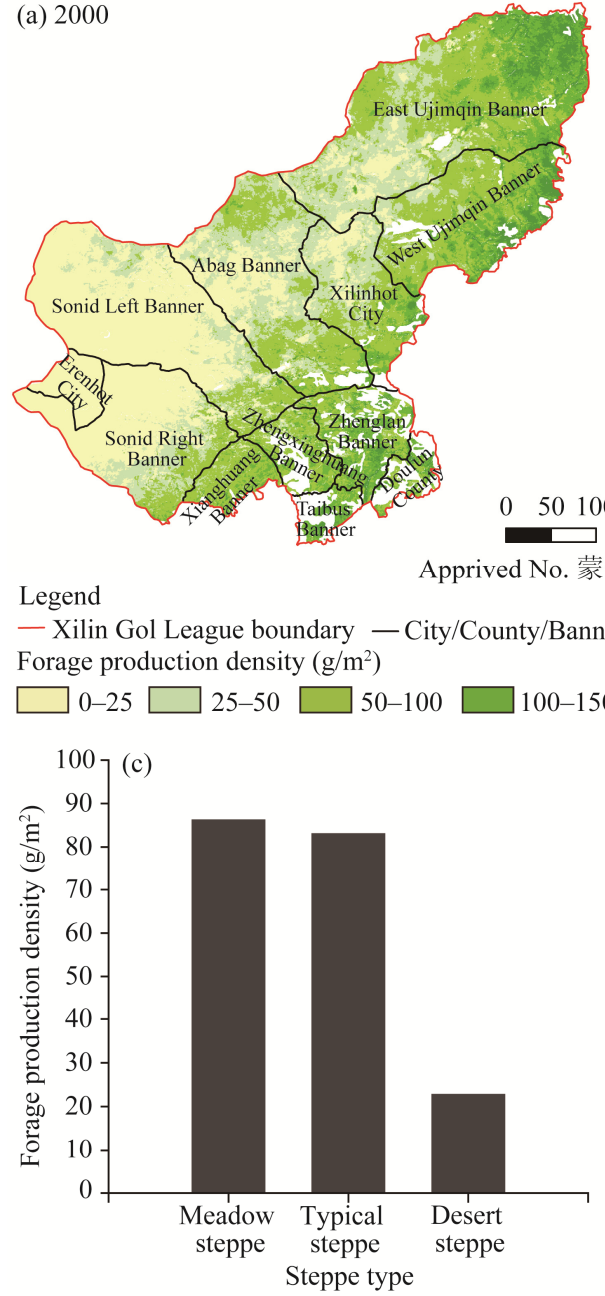

(b) 2015

$\stackrel{N}{N}$

(1)

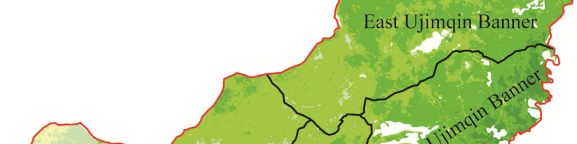

$\mathrm{km}$

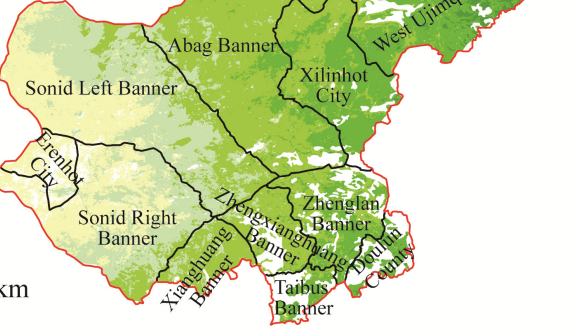




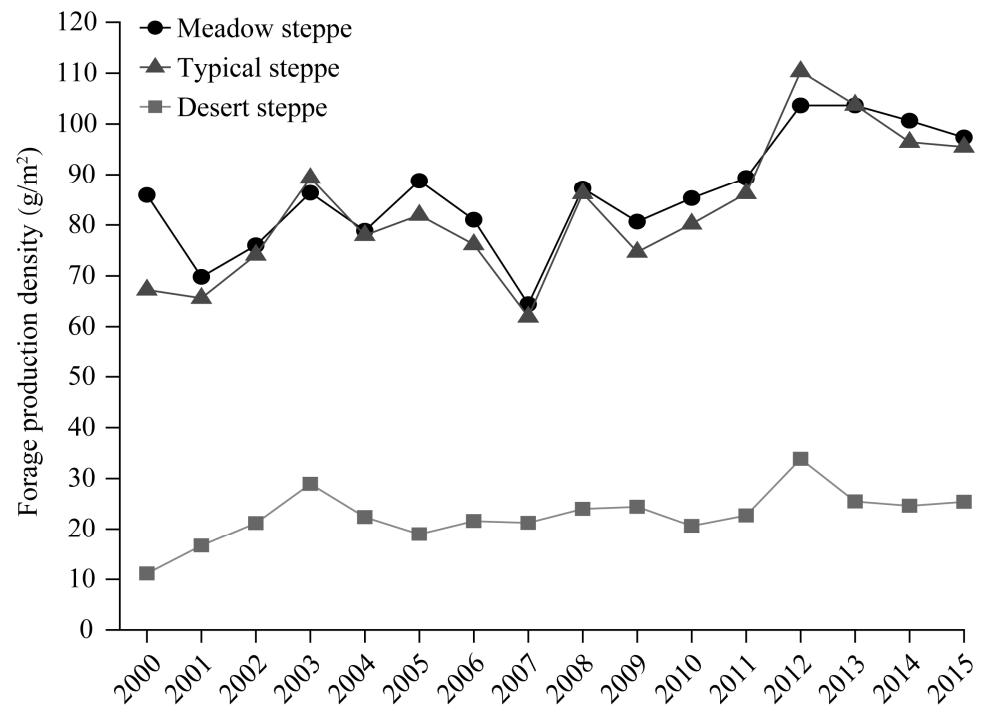

Fig. 3 Variations in the forage production density of different steppe types from 2000 to 2015

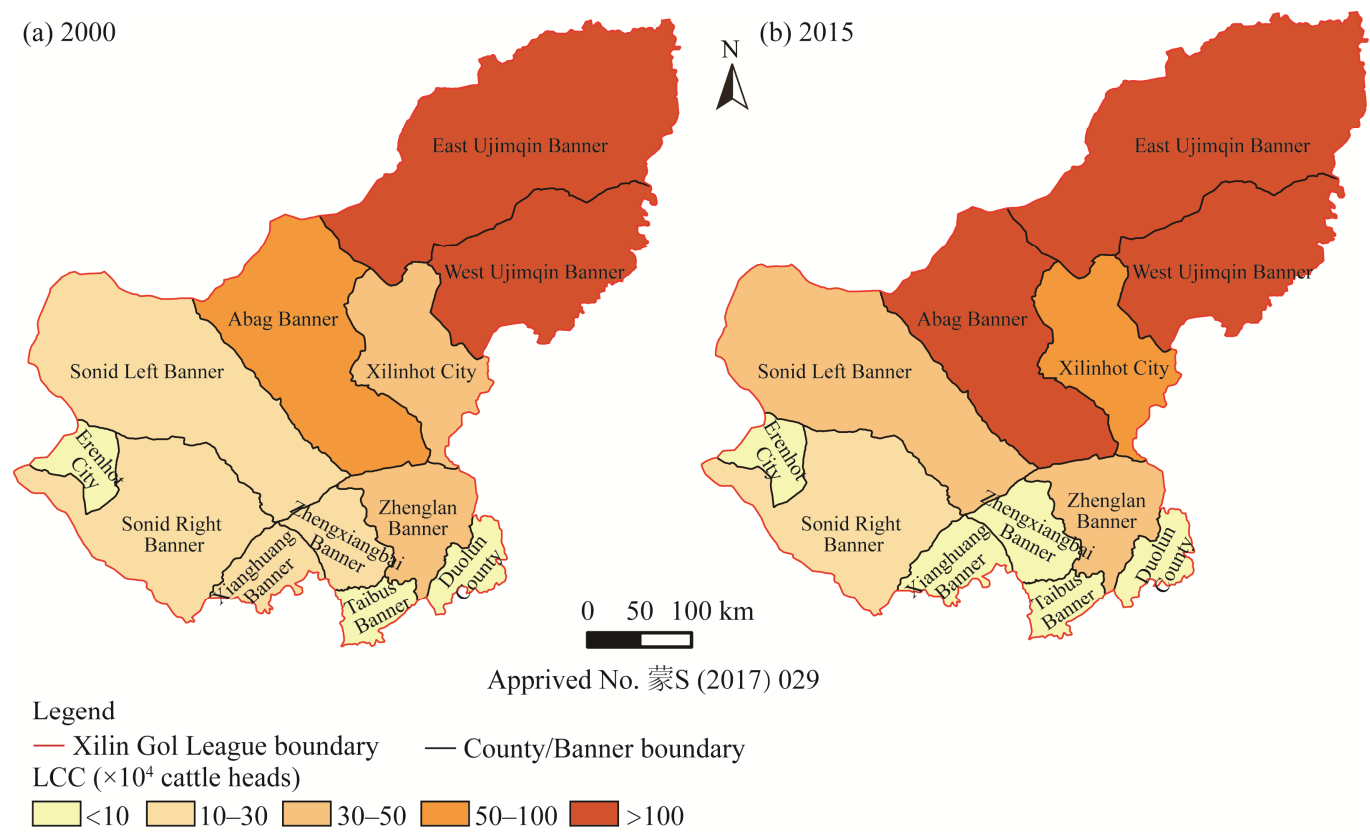

Fig. 4 Spatial patterns of the livestock carrying capacity (LCC) in the Xilin Gol League in 2000 (a) and 2015 (b)

Banner and Zhengxiangbai Banner decreased by $28.06 \%$ and $13.25 \%$, respectively. Furthermore, the changes within each city, county, or banner were spatially heterogeneous (Fig. 4). The forage-livestock balance level varied with scale, time, and space. At the regional scale, the overgrazing rate exhibited a strong fluctuation, with a higher rate in the early $2000 \mathrm{~s}(48.15 \%$ in 2000 and $28.03 \%$ in 2001). The forage-livestock balance was achieved in other years, and grazing potential was even observed from 2008 to 2013 (Table 1).

We classified the Xilin Gol League into three categories according to the trend and value of the overgrazing rate for the period 2000-2015. The first was overgrazing region $\left(4.86 \times 10^{4} \mathrm{~km}^{2}\right)$, including Duolun County, Taibus Banner, Sonid Right Banner, Xianghuang Banner, Zhenglan Banner, and Zhengxiangbai Banner, where the average overgrazing rate was in the range of $24.10 \%-234.89 \%$ (Fig. 5). However, the overgrazing rates in Duolun County, Taibus Banner, Sonid Right Banner, and Zhenglan Banner still exhibited a slight increasing trend. Another group 
consisted of forage-livestock balance cities and banners $\left(7.69 \times 10^{4} \mathrm{~km}^{2}\right)$, where the overgrazing rate remained stable at approximately zero from 2000 to 2015, including Xilinhot City, Abag Banner, and Sonid Left Banner (Fig. 5). The remaining cities and banners $\left(7.14 \times 10^{4} \mathrm{~km}^{2}\right)$ formed the third group, including Erenhot City, East Ujimqin Banner, and West Ujimqin Banner, which still exhibited potential for grazing, while Erenhot City exhibited a trend of overgrazing (Fig. 5).

At the village scale, we found that the forage-livestock balance in different villages varied significantly, according to the field survey conducted in the overgrazed typical steppe of Zhenglan Banner. In Baoshaodai Town, over half of the villages experienced overgrazing, $75 \%$ of which had an overgrazing rate that exceeded $30.00 \%$. The condition was better in Zagstei Town; however, a threat of overgrazing remained. Only the villages of Bayinnaoer, Bayinwulan, Xiretu, and Saihannaoer exhibited a grazing potential (Table 2).

Table 1 Forage-livestock balance dynamics from 2000 to 2015 in the Xilin Gol League

\begin{tabular}{cccc}
\hline Year & Proper LCC $\left(\times 10^{6}\right.$ cattle heads $)$ & Actual livestock $\left(\times 10^{6}\right.$ cattle heads $)$ & Overgrazing rate $(\%)$ \\
\hline 2000 & 2.76 & 4.09 & 48.15 \\
2001 & 2.61 & 3.34 & 28.03 \\
2002 & 2.95 & 2.92 & -0.82 \\
2003 & 3.54 & 3.26 & -8.12 \\
2004 & 3.10 & 3.23 & 4.24 \\
2005 & 3.26 & 3.15 & -3.29 \\
2006 & 3.06 & 3.15 & 3.14 \\
2007 & 2.50 & 2.80 & 11.97 \\
2008 & 3.41 & 2.93 & -14.03 \\
2009 & 3.03 & 2.94 & -2.88 \\
2010 & 3.19 & 2.94 & -8.05 \\
2011 & 3.42 & 2.83 & -17.14 \\
2012 & 4.33 & 2.95 & -31.86 \\
2013 & 4.07 & 3.20 & -21.44 \\
2014 & 3.73 & 4.08 & 9.55 \\
2015 & 3.78 & 3.75 & -0.66 \\
\hline
\end{tabular}

Note: LCC, livestock carrying capacity; overgrazing rate $>0$ means the actual carrying capacity is higher than the reasonable carrying capacity, and overgrazing rate $<0$ means actual carrying capacity is lower than the reasonable carrying capacity.

\section{Discussion}

\subsection{Factors influencing forage production in the Xilin Gol steppe}

Owing to differences in the study period, steppe type, data source, and quantification method, the forage production values in the Xilin Gol steppe differed significantly with previous reports (Niu, 2001; Ma et al., 2008; Jin et al., 2011). The data range of forage production in the desert, typical, and meadow steppes were approximately 9.50-175.10, $17.00-310.10$, and $68.30-358.40 \mathrm{~g} / \mathrm{m}^{2}$, respectively (Table 3). In this study, the MOD17A3H NPP product was used to calculate the dry weight of aboveground biomass production. Our simulated values were generally consistent with the findings of Zhao (2014).

Our results indicated that the forage production pattern fluctuated. The forage production density of the Xilin Gol steppe decreased from the northeast to the southwest. Precipitation has been reported to be the main climatic factor affecting the forage production of the Xilin Gol steppe (Cao et al., 2011; Zhao et al., 2012; Gao et al., 2013). The change trend of annual precipitation in the study area was not notable, and the highest precipitation level reached 325.08 $\mathrm{mm}$ in 2012, which is consistent with the annual variations in the regional forage production (Fig. S1a). Further analysis indicated a strong positive correlation between forage production and precipitation, particularly in the growing season, as commonly observed in the Xilin Gol steppe 

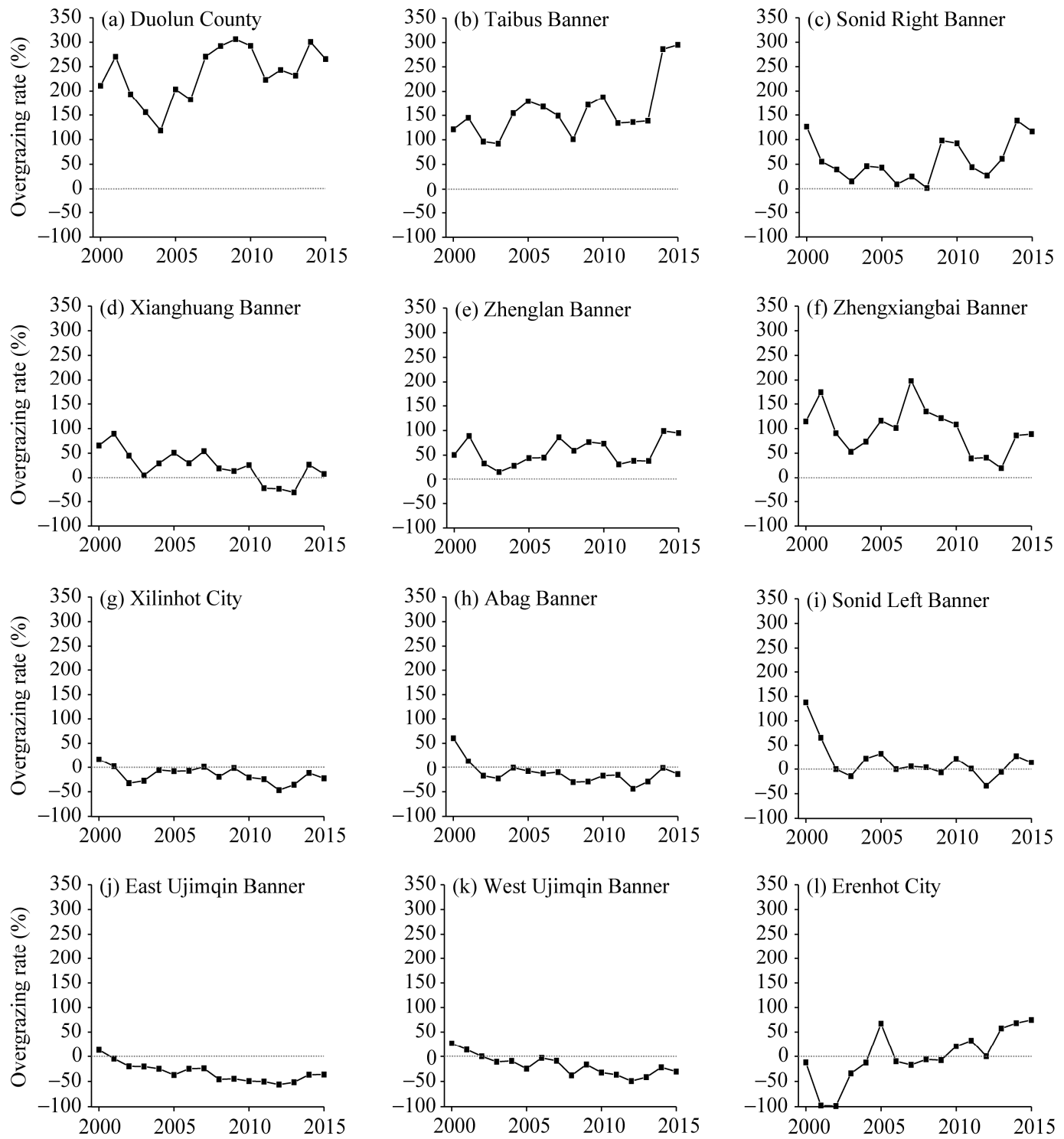

Fig. 5 Overgrazing rate of different cities, counties and banners in the Xilin Gol League from 2000 to 2015. Overgrazing rate $>0$ means the actual carrying capacity is higher than the reasonable carrying capacity, and overgrazing rate $<0$ means actual carrying capacity is lower than the reasonable carrying capacity.

(Fig. S1b). Moreover, the climate pattern of high temperature but low precipitation in the west area of the Xilin Gol steppe was not conducive to vegetation growth. Therefore, the forage production density of western parts, such as Sonid Left Banner, Erenhot City, and Sonid Right Banner, was low. However, the forage production density values in East Ujimqin Banner and West Ujimqin Banner were significantly higher than those in the other areas.

The impact of human activities on grasslands cannot be ignored. Previous studies reported that livestock grazing was mainly responsible for grassland degradation from the early 1980s to late the 1990s, while ecologically sound land-use policies have positively impacted vegetation restoration from 2000 onwards (e.g., Li et al., 2012). Additionally, owing to its good grassland resources, reasonable grazing behavior cannot easily cause overgrazing in the eastern region.

\subsection{Implementation of the "forage-livestock balance" policy}

We found that the general overgrazing rate fluctuated over time in the Xilin Gol steppe (Fig. 5). 
Table 2 Overgrazing rate in 21 villages of the Zhenglan Banner

\begin{tabular}{|c|c|c|c|c|}
\hline Town & Village & Proper LCC (cattle heads) & Actual livestock (cattle heads) & Overgrazing rate $(\%)$ \\
\hline \multirow{14}{*}{$\begin{array}{l}\text { Baoshaodai } \\
\text { Town }\end{array}$} & Halagaitu & 1034 & 1791 & 73.21 \\
\hline & Zhalute & 1524 & 1271 & -16.60 \\
\hline & Chahannao & 2114 & 1123 & -46.88 \\
\hline & Nairinao & 2173 & 1959 & -9.85 \\
\hline & Nudugai & 951 & 1320 & 38.80 \\
\hline & Gaogesitai & 1033 & 1649 & 59.63 \\
\hline & Mandulatu & 1985 & 2021 & 1.81 \\
\hline & Dengji & 1488 & 2073 & 39.31 \\
\hline & Xiarinao & 1568 & 2336 & 48.98 \\
\hline & Herimutu & 1257 & 1218 & -3.10 \\
\hline & Engeer & 2124 & 1830 & -13.84 \\
\hline & Kuisuhe & 1514 & 1690 & 11.62 \\
\hline & Sumutuhe & 456 & 1124 & 146.49 \\
\hline & Bayinbaogeli & 1161 & 1664 & 43.32 \\
\hline \multirow{7}{*}{$\begin{array}{l}\text { Zagstei } \\
\text { Town }\end{array}$} & Bayinwulan & 4820 & 4059 & -15.79 \\
\hline & Bayinnaoer & 5332 & 4020 & -24.61 \\
\hline & Bayinhanggai & 2979 & 4532 & 52.13 \\
\hline & Bayinbaogela & 1531 & 3049 & 99.15 \\
\hline & Saihannaoer & 7001 & 6304 & -9.96 \\
\hline & Hugejiletu & 1215 & 1424 & 17.20 \\
\hline & Xiretu & 2958 & 2616 & -11.56 \\
\hline
\end{tabular}

Table 3 Comparison of the results of different studies

\begin{tabular}{|c|c|c|c|c|}
\hline Study area & Study period & Steppe type & Forage production density $\left(\mathrm{g} / \mathrm{m}^{2}\right)$ & Reference \\
\hline \multirow{3}{*}{ Inner Mongolia } & \multirow{3}{*}{$2002-2005$} & Meadow steppe & $196.70^{\mathrm{a}}(68.30-358.40)^{\mathrm{b}}$ & \multirow{3}{*}{ Ma et al. (2008) } \\
\hline & & Typical steppe & $133.40^{\mathrm{a}}(17.00-310.10)^{\mathrm{b}}$ & \\
\hline & & Desert steppe & $56.60^{\mathrm{a}}(9.50-175.10)^{\mathrm{b}}$ & \\
\hline \multirow{3}{*}{ Inner Mongolia } & \multirow{3}{*}{$\begin{array}{l}\text { Scenario analysis } \\
\text { and prediction } \\
1981-1990\end{array}$} & Forest steppe & $204.00^{\mathrm{a}}$ & \multirow{3}{*}{ Niu (2001) } \\
\hline & & Typical steppe & $150.00^{\mathrm{a}}$ & \\
\hline & & Desert steppe & $63.00^{\mathrm{a}}$ & \\
\hline Inner Mongolia & $1981-2010$ & Typical steppe & $\begin{array}{c}186.30^{\mathrm{a}} \text { (Leymus chinensis steppe) } \\
138.30^{\mathrm{a}} \text { (Stipa grandis } \text { steppe) }\end{array}$ & Han and $\mathrm{Li}(2012)$ \\
\hline \multirow{3}{*}{ Xilin Gol steppe } & \multirow{3}{*}{ 2005-2012 } & Temperate meadow-steppe & $115.23^{\mathrm{a}}$ & \multirow{3}{*}{ Zhao et al. (2014) } \\
\hline & & Temperate steppe & $69.10^{\mathrm{a}}$ & \\
\hline & & Temperate desert-steppe & $27.23^{\mathrm{a}}$ & \\
\hline \multirow{3}{*}{ Xilin Gol steppe } & \multirow{3}{*}{$2000-2015$} & Meadow steppe & $86.18 \pm 10.95^{\mathrm{c}}$ & \multirow{3}{*}{ This study } \\
\hline & & Typical steppe & $82.97 \pm 13.22^{\mathrm{c}}$ & \\
\hline & & Desert steppe & $22.70 \pm 4.87^{\mathrm{c}}$ & \\
\hline
\end{tabular}

Note: $a$, mean value; $b$, the data in parentheses represent the range values from the minimum to the maximum; $c$, mean $\pm \mathrm{SD}$.

Further correlation analyses indicated that the overgrazing rate was significantly and negatively correlated with forage production $(P<0.01$; Fig. 6). The spatial heterogeneity of the forage-livestock balance at the city and village scales may be related to the payment gap between government compensation for restoring the grassland ecosystem and the herder's preference (Zhen et al., 2014). The Household Production Responsibility System private property rights arrangement was implemented in Xilin Gol League in the early 1980s (Li et al., 2007), and previous research found that the policy has led to soaring stock density and severe vegetation degradation for almost 20 a ( $\mathrm{Li}$ et al., 2012). By the early 2000s, the government had allocated land to herders according to the population and total pasture area in each village. To improve 
grassland ecosystems and the herders' quality of life, the central and local governments of Xilin Gol League published compensation standards. The latest policy of minimum standard of annual compensation awarded to herders is $45 \mathrm{CNY} / \mathrm{hm}^{2}$ for the forage-livestock balance, and 135 $\mathrm{CNY} / \mathrm{hm}^{2}$ for grazing prohibition in forestlands and shrublands. These compensation rates caused an imbalance between regions; those with vast and highly productive pastures, such as East Ujimqin Banner and West Ujimqin Banner, received more pasture and payment, and their income was higher than that in the western banners, such as Zhenglan Banner. Taking villages in Zhenglan Banner as an example, the per capita pasture area in Bayinnaoer village was $37 \mathrm{hm}^{2}$, while those in the severely overgrazed villages of Xiretu and Sumutuhe were only 25 and $11 \mathrm{hm}^{2}$, respectively. This explains the large difference in the forage-livestock balance level, to an extent. Although the local government has tried to adjust in different areas, a more comprehensive assessment based on in-depth scientific research is needed. Our interviews in Zhenglan Banner indicated that herders have recognized the grassland degradation caused by overgrazing along with natural disasters, such as heavy snowfall, severe wind erosion, and drought. However, they need to maintain traditional animal husbandry and raise more cattle to support their livelihoods.

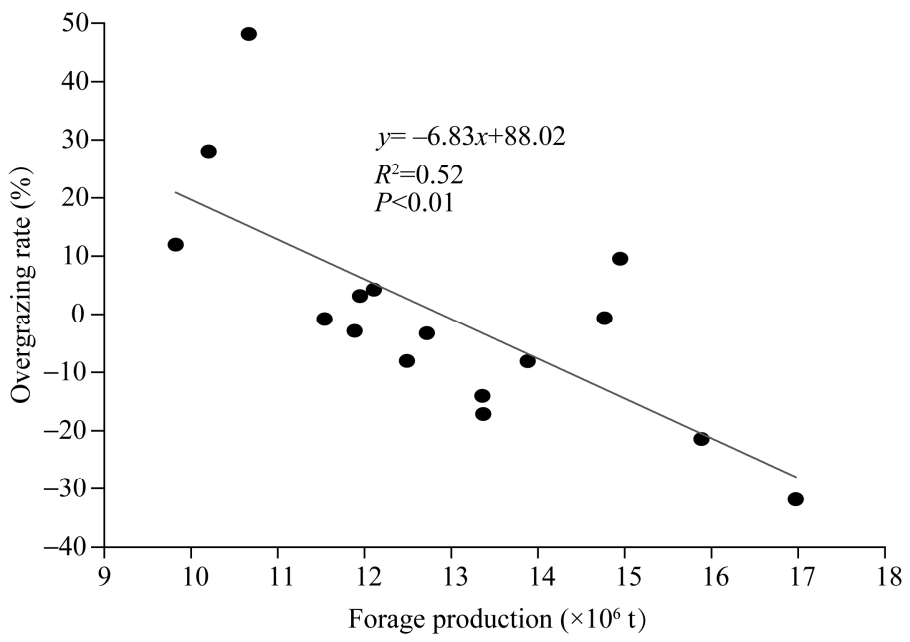

Fig. 6 Correlation between overgrazing rate and forage production from 2000 to 2015

\subsection{Recommendations for sustainable grasslands and ecosystem services}

To improve the eco-environment and human well-being, several ecological projects have been promoted by the Chinese government since the 1970s particularly after 2000 (Bryan et al., 2018), such as "Grain for Green" (Jia et al., 2014), "Returning grazing land to grassland" (Shao et al., 2016), and "Forage-livestock balance" (Hu et al., 2019). The dynamic balance between livestock and grassland is mainly maintained through the arrangement and planning of grazing intensity, area, and time (year-round grazing prohibition, seasonal grazing prohibition, or rotational grazing) (Chen, 2014; Xu, 2014). These projects were implemented in China in 2000 and they have greatly improved the ecological efficiency of grasslands (Hu et al., 2019). However, without effective management schemes, there will be no sustainable strategy to prevent land degradation and improve human well-being (Li et al., 2007; Zhen et al., 2014; Onatibia et al., 2019).

Our results indicated that, although half of the Xilin Gol steppe achieved a forage-livestock balance, regions with lower precipitation or sandy soils still experienced overgrazing. The livestock intensity is affected by many factors, such as grassland property rights and time elapsed from summer to winter pasture (Huang et al., 2017; Li et al., 2018). Therefore, based on our findings, we propose the following important recommendations, particularly for grazing management at local and regional scales, to achieve sustainable grassland ecosystem services.

First, it is better to evaluate the LCC based on the location-specific grassland productivity, rather than using a certain value to represent the whole region (such as $0.15 \mathrm{cattle} / \mathrm{hm}^{2}$ in 
Zhenglan Banner). For pastures with severe grassland degradation (such as the eastern desertified region in Zhenglan Banner), grazing prohibition throughout the year along with grass seeding should be adopted. Season- and location-based calculations of the LCC are required in moderate, non-degraded, and restored grasslands. This will require the associated scientific results to be converted into practical application strategies.

Second, location-based ecological compensation should be calculated to reduce expectation gaps between herders, and between herders and officials. From the interviews conducted in this study, we found that herders have recognized the requirement for environmental protection and are willing to accept compensation payments to mitigate their economic losses. However, both our survey and previous studies reported a certain gap between the expectation of herders and government budget, which affected the initiative of herders toward grassland restoration (Zhen et al., 2014). Compensation according to pasture area per capita also caused an equality issue between herders, some of whom could not support their livelihood by the current payment rates and need intensive grazing. Therefore, compensation for restoring grasslands should consider the extent of land degradation and trade-offs between herders and the government.

Third, infrastructure, particularly fodder factories, should be constructed nearby to reduce costs and raise the living standards of residents. In traditional nomadic culture, herders live on grasslands with water (Adler et al., 2005). Although herders now have fixed pastures, they still live on grasslands away from cities and face high everyday living, children's education, and fodder transport costs. According to our survey, education and gas for transportation were the major expenditures for most households, excluding those having to pay for medical care. Herders in Zhenglan Banner were required to purchase fodder from East Ujimqin Banner and West Ujimqin Banner as there was insufficient available fodder nearby. Seeding for mowing and fodder provision in high-quality grasslands is an effective method for reducing livestock feeding costs and achieving a forage-livestock balance.

\subsection{Limitations and future prospects}

Our study provides a general understanding of the regional and local multi-year forage-livestock balance, allowing us to make the above recommendations for sustainable grassland management at the macro-scale based on long-term time-series data for 2000-2015. Moreover, based on our field survey, herders are generally conducted livestock trading and slaughtering, and supplementary feeding activities in the Xilin Gol steppe at the end of the year. However, our study is an estimation of the proper LCC in the steppe growing season in the study area; therefore, we did not consider other forage sources. In future work, we will consider seasonal variations and winter supplementary feeding to evaluate the pattern of the forage-livestock balance within one year.

\section{Conclusions}

The forage production and livestock carrying capacities in the Xilin Gol steppe decreased from the meadow steppe in the east to the desert steppe in the west. The forage-livestock balance level fluctuated during the growing seasons from 2000 to 2015, and there was a negative correlation between overgrazing rate and forage production. Although approximately half of the region (East Ujimqin Banner, West Ujimqin Banner, etc.) achieved a forge-livestock balance, our data revealed severe overgrazing in the southern desert steppe. Based on these findings, we propose the application of differential management, including season-based livestock carrying constraints, location-based ecological compensation payments, and a low-cost fodder provision industry in the Xilin Gol steppe. These measures should aid grazing pastures while harmonizing the relationship between animal husbandry and environmental restoration, whereby the development goals, such as the eradication of poverty and land degradation neutrality by 2030 , become attainable.

\section{Acknowledgements}

This work was supported by the National Natural Science Foundation of China (41971130) and the "Research on 
the Sustainable Utilization of Desertified Lands in the Otindag Sandy Land, China" Program. We thank Dr. ZHANG Shuai, Dr. SAI Ke, Dr. WANG Chunyuan, and Mr. ZHAO Jilin at Beijing Forestry University for aiding in the field survey. We also thank the staff of the Zhenglan Banner government in Inner Mongolia Autonomous Region of China as translators from Mongolian to Chinese in the field survey.

\section{References}

Abbasi T, Abbasi S A. 2016. Reducing the global environmental impact of livestock production: the mini livestock option. Journal of Cleaner Production, 112(112): 1754-1766.

Adler P B, Hall S A. 2005. The development of forage production and utilization gradients around livestock watering points. Landscape Ecology, 20(3): 319-333.

Atsbha T, Desta A B, Zewdu T. 2019. Carbon sequestration potential of natural vegetation under grazing influence in Southern Tigray, Ethiopia: implication for climate change mitigation. Heliyon, 5(8), doi: 10.1016/j.heliyon.2019.e02329.

Batunacun, Nendel C, Hu Y F, et al. 2018. Land-use change and land degradation on the Mongolian Plateau from 1975 to 2015-A case study from Xilingol, China. Land Degradation \& Development, 29(6): 1595-1606.

Bryan B A, Gao L, Ye Y Q, et al. 2018. China's response to a national land-system sustainability emergency. Nature, 559(7713): 193-204.

Bureau of Statistics of Inner Mongolia Autonomous Region. 2000-2015. Inner Mongolia Statistical Yearbook. Beijing: China Statistics Press. (in Chinese)

Cao L G, Liu P X, Zhang K X, et al. 2011. Analysis on Response of Grasslands to Climate Change and Its Spatial Difference in Xilin Gol League. Arid Zone Research, 28(5): 789-794. (in Chinese)

Chen Y. 2014.Research of the farmers' illegal grazing behavior under the grazing prohibition policy-A case of Yanchi county in Ningxia, China. Journal of Arid Land Resources and Environment, 28(10): 31-36. (in Chinese)

Chi D K, Wang H, Li X B, et al. 2018. Assessing the effects of grazing on variations of vegetation NPP in the Xilingol Grassland, China, using a grazing pressure index. Ecological Indicators. 88: 372-383.

Editorial Committee for Vegetation Map of China. 2007. Vegetation Atlas of China. Beijing: Geological Publishing House. (in Chinese)

Fang J Y, Liu G H, Xu S L. 1996. Carbon pool of terrestrial ecosystem in China. Beijing: China Environmental Science Press, 391-397. (in Chinese)

Galt D, Molinar F, Navarro J, et al. 2000. Grazing Capacity and Stocking Rate. Rangelands Archives, 22(6): 7-11.

Gao T, Yang X C, Jin Y X, et al. 2013. Spatio-Temporal Variation in Vegetation Biomass and Its Relationships with Climate Factors in the Xilingol Grasslands, Northern China. PLoS ONE, 8(12), doi: 10.1371/journal.pone.0083824.

Guo B, Zang W Q, Yang F, et al. 2020. Spatial and temporal change patterns of net primary productivity and its response to climate change in the Qinghai-Tibet Plateau of China from 2000 to 2015. Journal of Arid Land, 12(1):1-17.

Han X G, Li L H. 2012. Mechanism of grassland ecosystem maintenance in Inner Mongolia. Beijing: China Agricultural University Press, 5-6. (in Chinese)

Hao L Z, Liu S J, Wu K X, et al. 2011. Study on the evaluation of grass nutrition and carrying capacity in alpine grassland of Kobresia hastily in Maduo County. Chinese Journal of Grassland, 33(1): 84-89. (in Chinese)

Hao L, Sun G, Liu Y Q, et al. 2014. Effects of precipitation on grassland ecosystem restoration under grazing exclusion in Inner Mongolia, China. Landscape Ecology, 29(10): 1657-1673.

Hao R F, Yu D Y, Liu Y P, et al. 2017. Impacts of changes in climate and landscape pattern on ecosystem services. Science of The Total Environment, 579: 718-728.

Hobbs N T, Swift D M. 1985. Estimates of habitat carrying capacity incorporating explicit nutritional constraints. Journal of Wildlife Management, 49(3): 814-822.

Hu Z M., Zhao Z, Zhang Y, et al. 2019. Does 'Forage-Livestock Balance' policy impact ecological efficiency of grasslands in China? Journal of Cleaner Production, 207: 343-349.

Huang W, Bruemmer B, Huntsinger L. 2017. Technical efficiency and the impact of grassland use right leasing on livestock grazing on the Qinghai-Tibetan Plateau. Land Use Policy, 64(64): 342-352.

Jia X Q, Fu B J, Feng X M, et al. 2014. The tradeoff and synergy between ecosystem services in the Grain-for-Green areas in Northern Shaanxi, China. Ecological Indicators, 43(1): 103-113.

Jin Y X, Xu B, Yang X C, et al. 2011. Remote Sensing Dynamic Estimation of Grass Production in Xilinguole, Inner Mongolia. 
Scientia Sinica (Vitae), 41(12): 1185-1195. (in Chinese)

Kemp D, Han G D, Hou X Y, et al. 2013. Innovative grassland management systems for environmental and livelihood benefits. Proceedings of the National Academy of Sciences of the United States of America, 110(21): 8369-8374.

Li A, Wu J G, Huang J H. 2012. Distinguishing between human-induced and climate-driven vegetation changes: a critical application of RESTREND in Inner Mongolia. Landscape Ecology, 27(7): 969-982.

Li A, Wu J G, Zhang X Y, et al. 2018. China's new rural "separating three property rights" land reform results in grassland degradation: Evidence from Inner Mongolia. Land Use Policy, 71: 170-182.

Li G, Wang D L, Xin, X P, et al. 2009. Analysis of grassland carrying capacity and grassland livestock balance in Xilinhot City. Pratacultural Science, 26(1): 87-93. (in Chinese)

Li W J, Ali S H, Zhang Q. 2007. Property rights and grassland degradation: A study of the Xilingol Pasture, Inner Mongolia, China. Journal of Environmental Management, 85(2): 461-470.

Liu H J, Yin S Y, Sun C, et al. 2015. Temporal and spatial variation of net primary productivity (NPP) and its responses with climatic changes in the Xilingol grassland from 2000 to 2010. Pratacultural Science, 32(11): 1709-1720. (in Chinese)

Ma W H, Yang Y H, He J S, et al. 2008. Above- and belowground biomass in relation to environmental factors in temperate grasslands, Inner Mongolia. Science China C: Life Sciences, 51(3): 263-270.

Ministry of Agriculture of the People's Republic of China. 2015. Calculation of Rangeland Carrying Capacity (NY/T635-2015). [S/OL]. [2019-07-18]. https://www.lddoc.cn/p-106633.html.

Ni J. 2002. Carbon storage in grasslands of China. Journal of Arid Environments, 50(2): 205-218.

Niu J M. 2001. Impacts Prediction of Climatic Change on Distribution and Production of Grassland in Inner Mongolia. Acta Agrestia Sinica, 9(4): 277-282. (in Chinese)

OECD-FAO (Organisation for Economic Cooperation and Development-Food and Agriculture Organization). 2011. OECD-FAO Agricultural Outlook 2011. [2020-08-01]. https://www.oecd-ilibrary.org/.

Onatibia G R, Aguiar M R. 2019. Grasses and grazers in arid rangelands: Impact of sheep management on forage and non-forage grass populations. Journal of Environmental Management, 235: 42-50.

Piao S L, Fang J Y, He J S, et al. 2004. Spatial distribution of grassland biomass in China. Chinese Journal of Plant Ecology, 28(4): 491-498. (in Chinese)

Ren H R, Shang Y J, Zhang S. 2020. Measuring the spatiotemporal variations of vegetation net primary productivity in Inner Mongolia using spatial autocorrelation. Ecological Indicators, 112: 106108, doi: 10.1016/j.ecolind.2020.106108.

Running S W, Nemani R R, Heinsch F A, et al. 2004. A continuous satellite-derived measure of global terrestrial primary production. BioScience, 54(6): 547-560.

Running S W, Mu Q Z, Zhao M S. 2015. MOD17A3 MODIS/Terra Gross Primary Productivity Yearly L4 Global $1 \mathrm{~km}$ SIN Grid. NASA EOSDIS Land Processes DAAC. [2019-04-17]. https://pdaac.usgs.gov/products/mod17a3hgfv006/.

Running S W, Zhao M S. 2015. User's Guide: Daily GPP and Annual NPP (MOD17A2/A3) Products. NASA Earth Observing System MODIS Land Algorithm. [2020-04-23]. http://www.ntsg.umt.edu/files/modis/MOD17UsersGuide2015_v3.pdf

Shao H Y, Sun X F, Wang H X, et al. 2016. A method to the impact assessment of the returning grazing land to grassland project on regional eco-environmental vulnerability. Environmental Impact Assessment Review, 56: 155-167.

Tilman D, Reich P B, Knops J M H, et al. 2001. Diversity and productivity in a long-term grassland experiment. Science, 294(5543): 843-845.

Tong C, Wu J G, Yong S, et al. 2004. A landscape-scale assessment of steppe degradation in the Xilin River Basin, Inner Mongolia, China. Journal of Arid Environments, 59(1): 133-149.

White R P, Murray S, Rohweder M, et al. 2000. Pilot analysis of global ecosystems: grassland ecosystems. Washington D.C.: World Resources Institute.

Xu B, Yang X C. 2009. Calculation of grass production and balance of livestock carrying capacity in rangeland region of Northeast China. Geographical Research, 28(2): 402-408. (in Chinese)

Xu M Y. 2014. A review of grassland carrying capacity: perspective and dilemma for research in China on "forage-livestock balance". Acta Prataculturae Sinica, 23(5): 321-329. (in Chinese)

Yu M, Ellis J E, Epstein H E. 2004. Regional analysis of climate, primary production, and livestock density in inner Mongolia. Journal of Environmental Quality, 33(5): 1675-1681.

Zhang J P, Zhang L B, Liu W L, et al. 2014. Livestock-carrying capacity and overgrazing status of alpine grassland in the Three-River Headwaters region, China. Journal of Geographical Sciences, 24(2): 303-312.

Zhao F, Xu B, Yang X C, et al. 2014. Remote sensing estimates of grassland aboveground biomass based on MODIS net 
primary productivity (NPP): A case study in the Xilingol grassland of Northern China. Remote Sensing, 6: 5368-5386.

Zhao M S, Running S W. 2010. Drought-induced reduction in global terrestrial net primary production from 2000 through 2009. Science, 329(5994): 940-943.

Zhao Y Y, He C Y, Zhang Q F. 2012. Monitoring vegetation dynamics by coupling linear trend analysis with change vector analysis: a case study in the Xilingol steppe in northern China. International Journal of Remote Sensing, 33(1): $287-308$.

Zhao Y Y, Wu J G, He C Y, et al. 2017. Linking wind erosion to ecosystem services in drylands: a landscape ecological approach. Landscape Ecology, 32(12): 2399-2417.

Zhao Y Y, Xin Z B, Ding G D. 2018. Spatiotemporal variation in the occurrence of sand-dust events and its influencing factors in the Beijing-Tianjin Sand Source Region, China, 1982-2013. Regional Environmental Change, 18(8): 2433-2444.

Zhao Y Y, Liu Z F, Wu J G. 2020. Grassland ecosystem services: a systematic review of research advances and future directions. Landscape Ecology, 35(4): 793-814.

Zhen L, Li F, Yan H M, et al. 2014. Herders' willingness to accept versus the public sector's willingness to pay for grassland restoration in the Xilingol League of Inner Mongolia, China. Environmental Research Letters, 9(4): 045003, doi: 10.1088/1748-9326/9/4/045003. 


\section{Appendix}
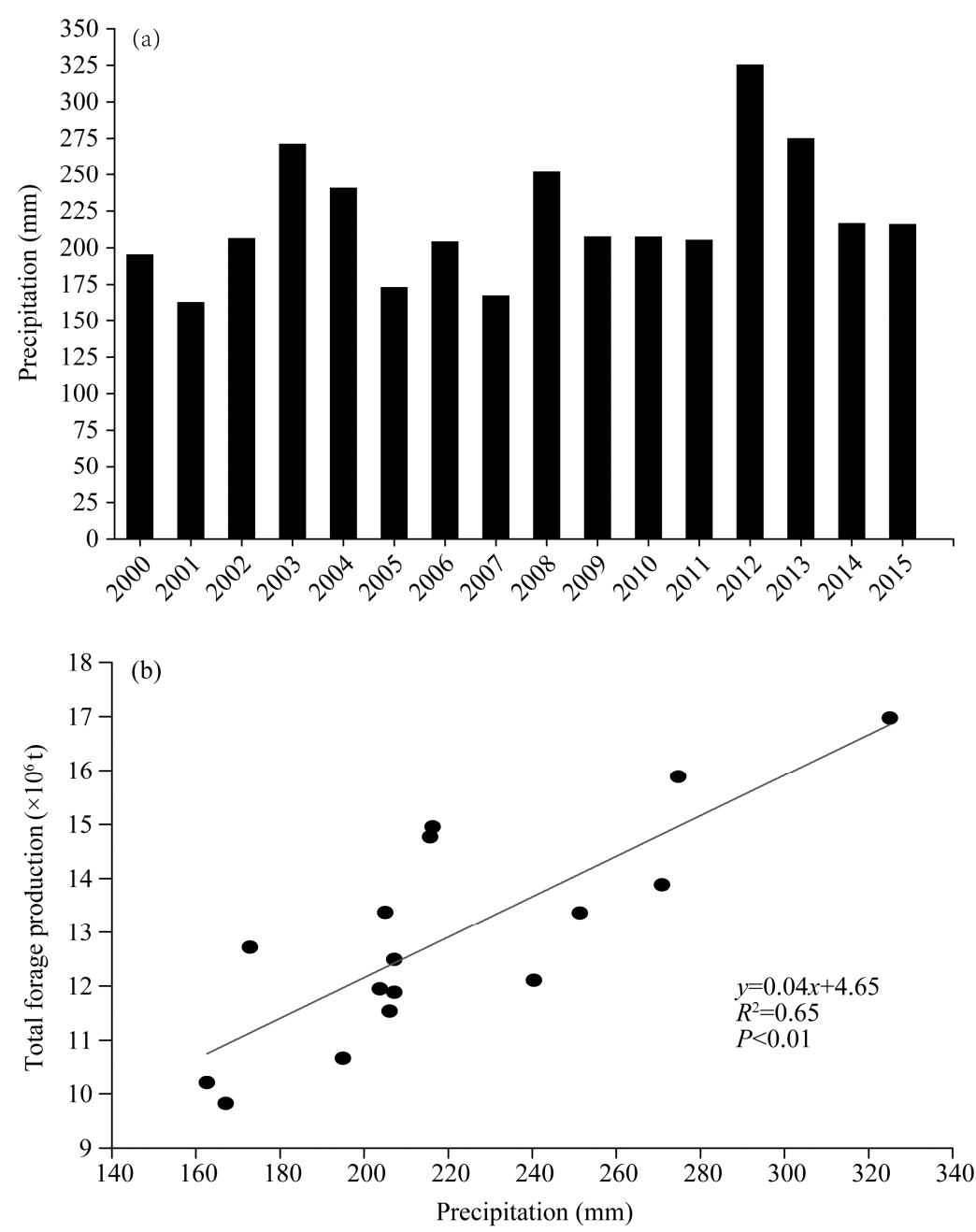

Fig. S1 Changes in precipitation (a) from 2000 to 2015 and relationship between precipitation and total forage production (b) in the Xilin Gol steppe 
Table S1 Total annual forage production in the Xilin Gol League

\begin{tabular}{|c|c|c|c|c|c|c|}
\hline \multirow[b]{2}{*}{ Year } & \multicolumn{6}{|c|}{ Forage production $\left(\times 10^{6} \mathrm{t}\right)$} \\
\hline & $\begin{array}{c}\text { Abag } \\
\text { Banner }\end{array}$ & $\begin{array}{l}\text { East Ujimqin } \\
\text { Banner }\end{array}$ & $\begin{array}{l}\text { Duolun } \\
\text { County }\end{array}$ & $\begin{array}{l}\text { Erenhot } \\
\text { City }\end{array}$ & $\begin{array}{c}\text { Sonid Right } \\
\text { Banner }\end{array}$ & $\begin{array}{c}\text { Sonid Left } \\
\text { Banner }\end{array}$ \\
\hline 2000 & 1.17 & 3.36 & 0.20 & 0.03 & 0.50 & 0.68 \\
\hline 2001 & 1.37 & 3.23 & 0.18 & 0.03 & 0.39 & 0.81 \\
\hline 2002 & 1.66 & 3.57 & 0.19 & 0.05 & 0.48 & 1.01 \\
\hline 2003 & 2.02 & 3.88 & 0.21 & 0.07 & 0.72 & 1.28 \\
\hline 2004 & 1.52 & 3.59 & 0.22 & 0.06 & 0.64 & 0.99 \\
\hline 2005 & 1.61 & 4.30 & 0.22 & 0.05 & 0.47 & 0.87 \\
\hline 2006 & 1.58 & 3.53 & 0.23 & 0.05 & 0.56 & 0.98 \\
\hline 2007 & 1.45 & 2.66 & 0.19 & 0.05 & 0.47 & 1.00 \\
\hline 2008 & 1.89 & 4.20 & 0.23 & 0.06 & 0.58 & 1.09 \\
\hline 2009 & 1.77 & 3.85 & 0.21 & 0.06 & 0.52 & 1.15 \\
\hline 2010 & 1.65 & 4.15 & 0.21 & 0.05 & 0.52 & 0.95 \\
\hline 2011 & 1.64 & 4.37 & 0.25 & 0.05 & 0.59 & 1.03 \\
\hline 2012 & 2.66 & 5.09 & 0.24 & 0.08 & 0.79 & 1.55 \\
\hline 2013 & 2.20 & 5.01 & 0.26 & 0.06 & 0.68 & 1.20 \\
\hline 2014 & 1.99 & 5.01 & 0.25 & 0.06 & 0.58 & 1.13 \\
\hline \multirow[t]{2}{*}{2015} & 2.01 & 4.78 & 0.24 & 0.06 & 0.58 & 1.18 \\
\hline & \multicolumn{6}{|c|}{ Forage production $\left(\times 10^{6} \mathrm{t}\right)$} \\
\hline Year & $\begin{array}{l}\text { Taibus } \\
\text { Banner }\end{array}$ & $\begin{array}{l}\text { West Ujimqin } \\
\text { Banner }\end{array}$ & $\begin{array}{l}\text { Xilinhot } \\
\text { City }\end{array}$ & $\begin{array}{c}\text { Xianghuang } \\
\text { Banner }\end{array}$ & $\begin{array}{l}\text { Zhenglan } \\
\text { Banner }\end{array}$ & $\begin{array}{c}\text { Zhengxiangbai } \\
\text { Banner }\end{array}$ \\
\hline 2000 & 0.21 & 1.99 & 0.82 & 0.41 & 0.82 & 0.38 \\
\hline 2001 & 0.14 & 2.02 & 0.82 & 0.22 & 0.56 & 0.25 \\
\hline 2002 & 0.16 & 2.00 & 1.03 & 0.29 & 0.61 & 0.28 \\
\hline 2003 & 0.21 & 2.37 & 1.31 & 0.40 & 0.78 & 0.38 \\
\hline 2004 & 0.20 & 2.07 & 1.09 & 0.38 & 0.77 & 0.38 \\
\hline 2005 & 0.18 & 2.41 & 1.16 & 0.26 & 0.69 & 0.29 \\
\hline 2006 & 0.20 & 2.13 & 1.07 & 0.33 & 0.75 & 0.35 \\
\hline 2007 & 0.15 & 1.64 & 0.95 & 0.23 & 0.60 & 0.26 \\
\hline 2008 & 0.20 & 2.34 & 1.21 & 0.30 & 0.71 & 0.31 \\
\hline 2009 & 0.17 & 1.76 & 0.97 & 0.26 & 0.65 & 0.29 \\
\hline 2010 & 0.17 & 2.27 & 1.19 & 0.25 & 0.60 & 0.26 \\
\hline 2011 & 0.20 & 2.37 & 1.14 & 0.38 & 0.75 & 0.36 \\
\hline 2012 & 0.21 & 2.88 & 1.60 & 0.38 & 0.80 & 0.39 \\
\hline 2013 & 0.24 & 2.75 & 1.43 & 0.45 & 0.89 & 0.45 \\
\hline 2014 & 0.21 & 2.65 & 1.34 & 0.29 & 0.80 & 0.37 \\
\hline 2015 & 0.19 & 2.62 & 1.44 & 0.29 & 0.77 & 0.33 \\
\hline
\end{tabular}

